\title{
The Struggles of the Kretek Workers in Iksaka Banu's Novel, Sang Raja (The King)
}

\author{
Thera Widyastuti \\ Universitas Indonesia, INDONESIA \\ e-mail: thera.widyatuti@gmail.com
}

\begin{abstract}
The novel Sang Raja was written by Iksaka Banu. This novel shows the struggles of people who worked in Bal Tiga kretek cigarette factory in Kudus in the early 1900s, during the Dutch colonial era. The problem in this research is how the efforts of the people who worked in Bal Tiga kretek cigarette factory sustain the life of the factory. The research objective is to analyze and study the struggles of the workers in the kretek cigarette factory in their effort to sustain Bal Tiga kretek cigarette factory. This research is a qualitative research, employing the descriptive analysis method through the intrinsic (character and setting) and extrinsic (sociology of literature and history) approaches. The kretek cigarette workers formulated various strategies and promotions to help their factory to overcome competition among cigarette factories. In addition, the tobacco harvest failure in Zanzibar and Madagascar had a major impact on the world economy. Bal Tiga kretek cigarette factory in Kudus felt the brunt of this crisis. However, after the economic crisis had passed, the people in Kudus returned to work in kretek cigarette factories enthusiastically. The results of the study show the values of humanity of the struggles of the kretek workers.
\end{abstract}

Keywords: Effort; kretek; struggle; novel.

\section{INTRODUCTION}

Iksaka Banu is a widely-published Indonesian prose writer and a well-known artist. He won Pena Kencana Literary Award for his two short stories, "Mawar di Kanal Macan (Rose at the Tiger Canal)" in 2008 and "Seтиа untuk Hindia (All for Indies)" in 2009 as the top twenty best Indonesian short stories. His collection of short stories, entitled Seтиа untuk Hindia (All for Indies) received Kusala Sastra Khatulistiwa Literary Award in 2014.

This paper analyzes his 2017 novel, entitled Sang Raja (The King). The novel narrates the life of people working in a kretek cigarette factory that produced the famous Bal Tiga brand, in Kudus, in the early 1900s. Banu wrote the novel based on the facts that occurred in the kretek cigarette industry in the Dutch East Indies (now Indonesia), specifically in Kudus, a town in Central Java. It often happens that writers use events and facts of the past as a source of their inspiration to write stories. According to Teeuw (1988, p. 247), written facts are facts that occur(red) in the past, at present, and in the future. The use of the reality in the past or history in literary works produces what socalled historical fiction, in which writers use various scenes, characters, and historical events in their work. While the use of factual events in literature make it as a work of history (Kuntowijoyo, 1987, p. 27), writers have the freedom to use their imagination to "recreate" factual events in their work. The events are adapted in order that they fit with the stories they write. Some writers may attempt to incorporate facts into their literary works. Thus, their works seem to be closer to a sociological depiction, or they give an impression that they really feature a historical fact or note.

The novel discussed, Sang Raja, depicts various problems of human life in its interaction with the environment, society, and culture. This cannot be separated from aspects in society which include social, economic, historical, language, customs and culture. The existing aspects of life will affect the nature or characteristics and habits of people or individuals in a certain area or social environment. Therefore, literary works are created as a reaction to the existing realities of life, which are manifested, among others, in language, individual characters, and culture.

Based on the above background, the research problem focuses on how Bal Tiga kretek cigarette workers struggle for the sustainability of the factory. While the research objective is to analyze and study the struggles of kretek cigarette workers for the sustainability of the Bal Tiga factory. The primary source of this research is the novel Sang Raja by Iksaka Banu, published in 
2017. Meanwhile, the method used in this research is descriptive analysis method using intrinsic (character and setting) and extrinsic (sociology, literature and history) approaches.

Nurgiyantoro (2010, p. 166) argues that characters and characterizations, and their depictions in a story provide a clear picture on the ideas of the novel, and that the setting reflects the physical and social conditions represented in the novel as a whole. These intrinsic narrative elements are supported by the social and cultural phenomenon (Wiyatmi, 2008, p.2), which related to the historical aspects that include (1) the past to describe the chronological order, (2) the cause and effect relationship, (3) subjective truth due to the continuity of the issue, and (4) the past, present, and future events (Kartodirjo, 1992: 38).

There are two previous related studies on kretek cigarette workers. The first study, entitled Analysis of the Social Aspects in the Ratih Kumala's Gadis Kretek:Research on Sociology of Literature and Its Implementation as Senior High School Indonesian Language Teaching Materials, was conducted by Ivana Septiya Rahayu in 2018. The study shows that the setting of the novel reflects the life of the people living in that era. The second study is Nur Salah's Social Reality represented in Iksaka Banu's Sang Raja (2019), which discusses that the economic crisis the Javanese experienced under the Dutch colonial rule created complex events for them at that time. Many events occurred during colonialism and caused poverty for the Javanese.

\section{FINDINGS AND DISCUSSION}

The novel Sang Raja reveals the characters and settings that describe the struggles of Kretek cigarette workers of Bal Tiga factory in Kudus in the early 1900s. The main character is Philip Gerardus Rechterhand, or Filip, a man of Dutch descent who was born in the Dutch East Indies (now Indonesia). Both of his parents were native Dutch people who had lived for a long time in the Dutch East Indies, as depicted in the following quotations:

My name is Filipus Gerardus Rechterhand. Born in Kalipasir, Menteng, from a Dutch couple who had lived for a long time in the Dutch East Indies. My father was a retired national bank employee. He spent his old age by running a small hotel, Gordel van Smaragd, located on Kramat Pulo Street, not too far from our house. (p. 21)

Filip was the only son. He loved his birthplace, Kalipasir, Menteng area, in Batavia (now Jakarta), and felt comfortable being around the villagers around him.
Even though he was a Dutch boy, he mingled easily with the people in the village. He fancied the tan skin of the villagers. He said,

I am the only child. I was born and grew up here. I felt peaceful walking in the middle of rice fields, barefooted walking down trenches, irrigation channels, with one or two leeches tightly stuck to a calf. I am accustomed to humid weather, which "roasted" all of my body, and turned the complexion of my skin into red. I liked the smell of firewood which was licked by the flame of villagers' stoves in the morning. I admired the tan complexion of people who always greeted and gave me a smile whenever I passed by in front of them. (p. 98-99)

Since his childhood, Filip has always played with the villagers. Whenever his father's hotel clerk went to the market to buy supplies for the hotel, Filip always accompanied him. He also played with the children of his father's hotel employee. Filip loves his childhood in Kalipasir.

Unlike most of my Dutch peers, my childhood was full of thrilling adventures with the natives who worked as a houseboy, a maid, a coachman, or a gardener in my father's hotel. With a slingshot looping round my neck, also barefooted like most of the native children, I did not feel ashamed of going in and out of the market with Kadir, our houseboy, to buy supplies for the hotel, or secretly watching cockfights in Kalilio with Doelah, my father's coachman. Quite frequently, I went out playing marbles or flying kites with their children, who were around my age. (p. 23)

Filip represents the image of the Dutch colonial social stratification system based on race. The society in the Dutch East Indies was segregated into three social classes, in which the Europeans belonged to the first class, foreign Orientals the second class, and the natives the third class. As a European, Filip is at the top tier of this social stratification.

Filip graduated from Hogere Burgerschool (HBS), but he did not continue his study because he wanted to help his father manage their hotel, Gordel van Smaragd, on Jalan Kramat Pulo, Batavia. However, there was a deadly outbreak of Spanish Flu. Both of Filip's parents died because of the plague, leaving him in economic hardship. Consequently, Filip had to take care of the hotel. Unfortunately, hotel occupancy continued to decrease and forced him to find another job. His father's school friend in Amsterdam, Christiaan Poolman, offered him a job in the largest kretek cigarette factory in Kudus. Filip accepted his offer and worked in the financial department of the factory. 
"The name of the factory is NV Nitisemito, and its brand name is Bal Tiga. The owner is a Javanese man. That company is so large; thus, it is impossible for me to work only by myself there. I need an expert; a Dutch man who is capable to assist me in accounting. Today, I offer you this position," said Mr. Poolman. (p. 56)

Rechterhand. Filipus Rechterhand. Accountant. I start to work tomorrow, Monday. Today I look around the office. And, please, do not call me Sir. Just Filipus or Filip. (p. 126)

The relationship between Filip and Poolman illustrates how the preservation of colonial heritage is related to the paradigm shift of new colonial relations from the VOC (Vereenigde Oostindische Compagnie) era, the style of "trade relations" to "colonial relations." It developed a paternalistic system that is synonymous to fatherly leadership, in which the superiors view their subordinates as their own children who need to be groomed and protected (Legge, 1961).

Meanwhile, the figure who was presented as the one from the upper class of the natives was Goenawan Wirosoeseno, usually called Wirosoeseno, a Javanese priyayi. His father was an irrigation staff, and his mother was a famous batik maker in the village. $\mathrm{He}$ had an older sister named Djoemiran or Djoem. When NV Nitisemito had a job vacancy, he applied for the job and was accepted as the staff in the financial department. Wirosoeseno sent a letter to his family informing him of this good news.

I wrote the shortest letter to my family in Yogyakarta through Sister Djoem, with larger letters; sending my regards to Father, Mother, and Sister Djoem. Next year I will work as an employee in NV Nitisemito Bal Tiga Kudus. Financial department. (p. 83)

I stood up cleaning both of my hands, then extended them right toward him. "My name is Wirosoeseno, a staff at the financial department." (p.126)

Since he was a child, Wirosoeseno liked to study. Education is the most interesting thing in his life. His priyayi family background enabled him to pursue higher education.

When I was eight years old, Father placed me in a Volksschool or a village elementary school for three years. After that, he promised to send me to a Tweede Klasse School, known as Sekolah Ongko Loro. Actually, I was late in entering the elementary school. According to the Dutch rules, a proper basic education began when a child was six years old.(p. 39)
Wirosoeseno was well-known as a smart child. He was very good at school. All the questions the answer of which he could not find at home, Wirosoeseno found the answers at school. His curiosity made it hard to be silent, even for a moment. Wirosoeseno was very intelligent in mathematics. He was also an expert at making various crafts and also clever on calculations. $\mathrm{He}$ had an artistic talent, capable of making attractive ornaments and arts for school events.

Besides good at mathematics in the classroom, I was also known as skillful in creating various handicrafts. Every time the school held an event, such as celebrating the birthday of The Queen of the Netherlands on $31^{\text {st }}$ August or New Year's Day, I would be called by the teachers to help them making a lion insignia out of pulp paper, or a Dutch warship miniature, which was paraded during a carnival. Or simply decorating the school gate with young coconut palm leaves and bamboos. (p. 39)

Wirosoesno's intelligence amazed Mr. Zwartepen, a Catholic missionary. He offered a scholarship that enabled him to study in either Leergang Ambachts or Handels Onderwijs. Wiroseno decided to study in Handels Onderwijs, a trade school. He scholarship that Wiroseno got was one of the result of the Dutch Ethical Policy, initiated by Van Deventer. This policy was created as a means of carrying out the Dutch colonial government's ethical responsibility for the welfare of the colonial subjects, especially in the development of agriculture and education. Therefore, the native from the priyayi group could get Dutch education. In this way, the Dutch colonial government secured their loyalty.

Being a bright and skillful young man. Wiroseno was accepted to work in the financial department of the kretek cigarette factory. Then he was offered to be the marketing staff.

He was smart, logical, skillful, and seemed to have many good ideas. It was not surprising that he was interested in the Marketing and Promotion Department. (p. 148-149)

The joy was more complete, especially for myself because Mister Karmain took my hand warmly and said: "Wirosoeseno, I ask you for two things. Firstly, please take that mannequin to the front office door so that people can come to see it. Secondly, do you mind to move to the Marketing and Promotion Department? We need fresh ideas like this to be applied in our cigarette brand. (p. 127) 
The head of the cigarette factory asked Wirosoeseno to design a promotion to make in order to make the public know the cigarette better. He accepted this task happily, and his design won the director's favor. This made him very happy.

Mister Soedjoko commenced the meeting. Subsequently, in a coherent and clear fashion, he informed the detail of my proposal. It was hard to remember the feeling of that moment. I felt that my bowels were twisted, and my body shrunk ten times than the normal size. How could it not be, the sheets of proposal which I wrote them sleepily became a serious topic of discussion among the high officials of this factory. (p.142)

Mr. Nitisemito, the owner of the Tjap Bal Tiga cigarette factory, immediately approved Wirosoeseno's proposal. Instantly, Wirosoeseno earned the full trust of the factory's owner.

The social setting in the novel Sang Raja reflects the attitude of the Dutch people towards the Indonesians, which was commonly called Bumiputra. The Dutch felt they were socially higher than Bumiputra.

Filip's father noticed Filip's attitude towards those around him. He saw Filip playing and chatting with the natives, or the Bumiputera. He warned his son to behave as a European, the highest class in the social stratification in the Dutch East Indies.

"Filip, Father is not good in composing words. However, the point is: I like seeing you intently knowing and learning the life of indigenous people. It will be a valuable saving for the future. It will make you not easily fooled. It will make you know exactly how to use their talents and strength to support our needs, as well as their own good." (p. 24)

According to article 163 of Indische Staatsregeling (The Constitution of the Indies) in 1926, the population of the Dutch East Indies was categorized into three main groups, namely; 1) European or white people, especially the Dutch and other Europeans and other racial groups who had equal status with Europeans (gelijkstelling), 2) the Foreign Easterners (Oosterlingen), including Chinese, Arabs, Indians, Japanese and other Asians, and 3) the indigenous group or the Bumiputra, namely the indigenous people of Indonesia, called inlanders. The Inlanders are third-class citizens (onderdanen) who received discriminatory treatment not only in legal but also in government affairs (Simanjuntak, 1999, p. 1-2).

"You surely know, whether you like it or not, the nature has chosen us to be the leader of those people. And the good leader is the one who comprehends the life of his or her subordinates, but not to mingle with them." (p. 24)
The Dutch did not allow the indigenous people to mingle with them. Distance applied to everything. They were leaders, and they had to be respected. The indigenous people consisted of two major groups. The first group was the commoners, consisting of farmers and villagers. The second group was known as the elite or priyayi group, consisting of educated administrators, government officials and indigenous people who were better off, both in urban and rural areas.

Meanwhile, the setting of place in the novel Sang Raja, as depicted by the location of Tjap Bal Tiga cigarette factory, was Kudus, a city in central Central Java. The cigarette factory started from Langgardalem and then expanded to Jongenstraat.

"The factory is in the town of Kudus, to be precise in Langgardalem, Jagalan village. The office is on Jongenstraat. The office phone numbers are 1450," Lasinah smiled. (p. 51)

Behind the gate, there was a row of warehouses built from bamboo logs. It seemed that the warehouses were extended toward the back. Not sure how many. Meanwhile, in the front, there was a wide ground with barbed wire fences, and a main gate built from iron. In front of the main gate, there was a pair of cone-shaped monuments, which at a glance resembled inverted klobot cigarettes. On the top of the main gate, there was the name of the factory, installed in black colored welded iron lettering: Sigaretten Fabriek 'M. Nitisemito', Koedoes." (p. 76-77)

Along with the increasing demand for Bal Tiga kretek cigarettes, Nitisemito established a large factory in Jati Kudus village covering 6 hectares that could accommodate 15,000 workers with 12,000,000 cigarettes production each day (Margana, 2014, p. 61).

The cultural setting in the novel Sang Raja was reflected in the habit of local residents rolling their own cigarettes, and the origin of the discovery of kretek cigarettes which became widely known outside Java.

Starting from the establishment of trade relations between the Europeans and the Arabs, the natives of the Dutch East Indies were introduced to kretek cigarettes. At first, especially in Java, they rolled tobacco with dried corn leaves or klobot in Javanese, hence the name klobot cigarettes. Klobot was suitable for cigarette packs because it was hard. The shape of the klobot cigarettes were like an inverted cone, in which the butt was the pointed end. The flavor of the klobot cigarettes was not too flavorful. When they gained popularity, a number of factories produced them, and used various brand to sell them. Klobot cigarettes were popular especially among farmers because the cigarettes were affordable for them. 
"Put the tobacco blend carefully and spread it evenly on a sheet of triangle-shaped klobot which was ironed before, usually called besut. Roll it up carefully so that the klobot will not be torn, then tie the both ends with jinggo threads. Tie ten stick into one bunch, and after there are a lot of bunches, batil workers will trim both ends. Send them to conthong workers who are going to put them into their longsong or packs." (p. 91)

The tendency of the tendency of the natives to smoke kretek cigarettes gave opportunities for cigarette factories to produce various types of kretek cigarettes. Some of them added cloves to their klobot cigarettes. This kind of the kretek was more flavorful than the regular klobot cigarettes, but less pungent than klembak cigarettes which contained a mixture of tobacco, kawung, and menyan. Whenever they smoked it, the kretek made a crackling sound of burning tobacco. This sound was called kretek, and that was why cigarettes as such were called kretek cigarettes.

Klobot cigarettes were relatively were milder than klembak menyan cigarettes. It was said that they could clear the respiratory tract. Perhaps it was the secret that made them best-selling cigarettes. Cigarettes as such are were called kretek, and the term kretek gained popularity. Actually, the term was created from a word that resembled the crackling sound of the burnt clove when the cigarettes as such were burnt. (p.108)

There were no definitive documents on the emergence of kretek cigarette in the Dutch East Indies. However, according to the oral history of cigarette factory workers, kretek cigarettes were made by Haji Djamari. It was said that he had asthma and always rubbed his chest with clove oil. Then, he put cloves and mixed them with tobacco in his cigarette, and smoked them regularly. Unexpectedly, he felt that his health was getting better. Since then kretek cigarettes were known as medicinal cigarettes. Both those who were sick and those who were healthy liked this kind of cigarettes.

The demands for kretek cigarettes grew rapidly in the Dutch East Indies. Since then, the Dutch colonial administration opened tobacco plantations in various regions. Tobacco was imported from various regions in Java, especially from Temanggung in Central Java, which produced high quality tobacco.

"For those who do not know yet, the ingredients of cigarettes are tobacco, clove, sauce, and dried klobot. The tobacco is brought from various areas such as Muntilan, Magelang, Kranggan, arakan, Blabak, Bangilan, Padangan, and Kendal. However, most of them were from Temanggung." (p. 86)
The production of kretek cigarettes was closely connected to the way tobacco, the main ingredient, was processed. To produce good cigarettes, tobacco underwent several processes, namely (1) stringing, (2) fermentation, (3) sorting, (4) threshing, (5) dyeing, and (6) bundling. All these processes determined the quality of kretek cigarettes. Tobacco, the main ingredient, had to be stored properly in places that were free from pest. Damaged tobacco could cause huge loss for cigarette factories. Here was how to store tobacco leaves after they were picked by farmers from the plantation.

"Tobacco leaves are strung on their stems. Just string them loosely so that they will not be bruised or attach one to another. Then, put them on a kind of wide divans. The way to store them cannot be unsystematical. The stems must face upward. Leave them for 5 days.” (p. 87)

The way tobacco leaves are stored has a strong effect on the flavor and aroma of the cigarette. The longer tobacco is stored, the more flavorful and aromatic the cigarettes will be. This happens because the nicotine content will be getting higher. Kretek cigarettes produced from tobacco as such command higher prices because they are considered as high quality kretek cigarettes. The higher quality cigarettes have, the higher the nicotine content they have. The higher the nicotine content they have, the more flavorful and aromatic kretek cigarettes will be (Setiadji, 2003).

The blend of tobacco, cloves, and sauce will make the taste of kretek cigarettes flavorful. The sauce concocttion of each kretek cigarette factory is different. Thus, the sauce makes the cigarettes the specialty of the brand.

"As I have said, besides tobacco and clove, the flavor of cigarettes comes from their concoction of the sauce. The concoction may contain fruit extract, coffee extract, ginger extract, andmany more. Certainly, the sauce of Bal Tiga is not the same as the ones of other brands. In fact, the recipe is confidential." (p. 89)

The existence of the Bal Tiga kretek cigarette brand and its factories contribute to the development of the kretek cigarette industry in the Dutch East Indies. In 1906, Nitisemito began selling kretek cigarettes which were increasingly popular in Kudus. Just like other factories, he sold them in bundles without packaging or brand. Each bundle had ten sticks of cigarettes. He merely wrapped the bundle in newspaper. In 1908, he registered his business legally under the brand $\mathrm{Bal}$ Tiga, which meant "Three Balls." He wrapped the bundles in a proper packaging and put the brand $\mathrm{Bal}$ Tiga in it. He was the first person who sold packaged 
kretek cigarettes. Thus, he was the pioneer of the kretek cigarette industry in Kudus. Nitisemito's effort was seen as a milestone in the development of kretek cigarette industry in the Dutch East Indies and in Indonesia (Sahrodji, 2017).

Nitisemito was the first person who sold kretek cigarettes with packaging and brand. Previously, only sticks of klobot cigarettes or roll-your-own cigarettes, and without sauce added. Simply a blend of tobaccos and myrrh. Prior to this, Nitisemito also sold unbranded cigarettes, 25 sticks of klobot cigarettes in each bundle. At that time, they were sold for 2.5 cents for a small bundle and 3.5 cents for a bigger one. No packaging. All of them were simply wrapped in rolls of newspaper. (p. 110)

In the first half of the $20^{\text {th }}$ century, the Bal Tiga cigarettes produced by NV. Nitisemito was so famous that the Dutch Queen Wilhemina nicknamed Nitisemito as De Kretek Konning (King of Kretek). This was not an exaggeration because in 1938 Nitisemito employed 10,000 rolling stockers with the production of 10 million cigarettes per day with a market share in Java, Sumatra, Kalimantan, Singapore and the Netherlands (Nitisemito, 1980).

The presence of N.V. Nitisemito and the Bal Tiga kretek cigarette factory were one form of capitalism in Indonesia. Capitalism according to Karl Marx is a system in which the prices of goods and market policies are determined by the owners of capital in order to achieve maximum profit. Land ownership and property ownership were the two main individual rights that allowed N.V. Nitisemito to operate. Apart from the amount of production and sales, it benefited factory owners. The capitalist economic system relies on private property, the invisible hand, economic individualism, and free market competition. As the owner of the Bal Tiga kretek cigarette factory, Nitisemito gave his workers the freedom to market the products, such as using innovative promotions to deal with free market competition. The freedom on innovation and creativity for marketing the products showed the recognition of the abilities of his workers. Nitisemito understood that equal rights for freedom motivated the kretek workers to do their best for the factory. Implicitly, Nitisemito's attitude was against the discriminatory views indoctrinated by the Dutch colonial administration at that time.

Marketing management of Bal Tiga kretek cigarette factory was vigorous in its promotion. The management asked for a massive promotion so that the public knew the brand better. Several marketing strategies were planned to increase the sales. For example, using a modified truck for selling the cigarettes and giving glassware as gifts for purchasing the cigarettes.

We looked at a photo of a tricycle cart with a glass box on the front, which is usually used by Chinese for selling bread, but we could not yet guess what did Mister Karmain intend to with the photo.

"I want this truck to be modified. We change the walls of its storage compartment. Similar to that bread cart, we use glass instead. Inside the storage compartment, we display all the chinaware which will be exchanged with the cigarette packs. Later on, our promotion personnel will simply park the truck in the middle of an open-air market. It will quickly draw attention for sure. Around the truck, we place some tables, a cigarette kiosk, and a stage for entertainment. Just like what we carry out now." (p. 130-131)

One of the brilliant marketing idea was to modify a truck, by using glass as the walls of the storage compartment, in which chinaware and glassware gifts were displayed. Such promotions enticed people to buy cigarettes and took the gifts home. Others prefered to exchange cigarette packs for coupons, the prizes of which would be drawn at the factory.

Shortly after the music stopped, the man shouted loudly: "Come on, brothers! Today NV Nitisemito will give some gifts again. Don't miss it! Exchange Bal Tiga cigarettes, yes Bal Tiga, for various attractive gifts. Five packs of cigarettes for one china dinner plate or glass. Ten packs, you may take this original Japanese China tray. Twenty packs, you may take home this tea pot along with two cups and saucers. Or you may also exchange five packs for a coupon!"' (p. 50)

Another strategy was offering sponsorship because it could improve the brand image. According to D'Astous and Bitz (1995, p.6), sponsorship is one of communication tools where brand owners provide support in the form of money for events such as musical, social, or sporting events, with the purpose of making these successful, and at the same time the brand owners will get benefits in the form of consumers' brand awareness and image.

"To become a hoofdsponsor is a right suggestion," said Mister Karman. "It has an opportunity to be carried out continuously in the future, and not just at this moment." "Unfortunately, this idea can be easily imitated," added Mister Karman. "A Dutch made product has done it in movie theaters. The promotion was screened before the movie began. And sponsorship, particularly for a cigarette product, through traveling theaters like this has not been done yet by anyone.” (p.142) 
Becoming the main sponsor of a traveling theater group or stamboel was something new around Kudus, Semarang, Salatiga, and Yogyakarta, the targeted areas of Bal Tiga marketing. The stamboel, which was an Istanbul-style variety show and where the name came from, was a popular entertainment for the public in the Dutch East Indies. Stamboel groups travelled to a number of places; and thus, the promotion could reach potential consumers outside Kudus. A contract that lasted for a certain period of time was then made between NV Nitisemito and stamboel groups. The contract stipulated that these groups solely promoted Bal Tiga brand.

"As a reward, we support all their promotional needs. Banners, posters, tickets, pamphlets, and backdrops, on all of which them we place our $\mathrm{Bal}$ Tiga brand logo on certain positions that the audience can easily see." (p. 143)

Rewards for the stamboel groups were also given in the form of pamphlets distributed by cars and horse-drawn carriages.

Another promotional strategy was a raffle, with some attractive prizes, for the audience that is drawn on the last day of the show.

"We also add some information on the pamphlets for the spectators, that is, keeping their ticket stubs to be drawn for prizes, as suggested by Mister Karmain a moment ago. The first prize, a Simplex bicycle, will be announced on the last day. The second prize is a wall clock. The third prize is a set of chinaware. Consolation prize is 10 packs of Bal Tiga." (p. 145)

The promotional activities and rewards were given to the audiences of the stamboel, as well as to those went to events such as the Sekatenan, held by the palaces of Surakarta and Jogjakarta.

"Certainly, around the location, we will erect a stage for the prize announcement, together with our cigarette carts, as usual. So, all of these, later, will be our permanent promotion package or formula if we become a hoofdsponsor for traveling theaters, also Jaarmarkt night market and Sekatenan event." (p. 145)

The aggressive promotion was considered as a good way of increasing sales and production of the cigarettes. To help its marketing, the company rented Fokker planes to deliver flyers to several cities in Java. This is a historical record in the world of kretek cigarettes in the era of the Dutch East Indies.

At first, it was like the faint sound of humming bees. Then, it transformed into the roar of a lion. Up there, not too high from the position where we all gathered, I saw something. Twisting, snatching. It was a Fokker F.VIIb, a trimotor aircraft with a white nose. Its tail number could be read clearly, PK-AFC. The airplane of The Royal Netherlands Air Force was willing to be chartered by us for $f 200$ for every sortie to Bandung, Batavia, Semarang, and Surabaya prior to its military assignment to Australia. (p. 181)

The bazaar and art performances organized by $\mathrm{Bal}$ Tiga in Bandung were packed by visitors. Hundreds of people gathered at the city square. Some of them watched the singing and dancing performance, and the rest flocked the food and beverage stalls, game stalls, and cigarette stalls. The Fokker plane attracted the visitors. When it dropped thousands of white papers, they scrambled to take the fliers. The atmosphere was very festive.

Another marketing strategy adopted was using radio broadcast and cinema. N.V. Nitisemito, the company that owns Bal Tiga brand, founded a radio station called Bal Tiga Koedoesch Radio Vereeniging. In addition, the company also opened a cinema called Nitisemito Bioscoop. Both radio station and cinem were used for promoting Bal Tiga kretek cigarettes

"Just include the words Bal Tiga for the name of radio station. For instance, Bal Tiga Koedoesch Radio Vereeniging. So, every time in the opening program or at every possible occasion, when mentioning the identity of the radio, the broadcaster can repeat the words Bal Tiga as many times as possible.” (p. 215)

The proposal for a cinema was based on the idea of showing Bal Tiga's advertisement both before the film started and during the intermission.

"We can buy one of the government buildings, such as Oost Java Bioscoop building located in the east side of the town square. Then, we decorate it to make it more glamorous and stylish. Before the movie begins and during the intermission, we can screen our cigarette advertisements." (p. 216).

These various methods of promotions to raise the $\mathrm{Bal}$ Tiga's brand image brought a huge success. As a result, Bal Tiga became famous in Sumatra, Sulawesi and Kalimantan, even in the Netherlands. Sales increased dramatically and Bal Tiga reaped enormous profit. Nitisemito, the owner of the Bal Tiga kretek cigarette benefited from the increasing production and sales. In a capitalist economy, everyone is free to compete in business for maximum profit. Everyone is free to do various ways to win the competition. 
However, there were ups and downs in the kretek cigarette business. In 1929, N.V. Nitisemito received a telegram from Borsumij (Borneo Sumatra Handel Maatschappij), a clove importing company, informing the failure of clove harvests in Zanzibar and Madagascar. The kretek cigarette industry relied heavily on the clove harvest because the quality of the clove determined the taste of the cigarettes produced. The failure of the clove harvest had a serious impact on the cost of the cigarette production. This incident made the kretek cigarette industry shaken.

The content of the telegram was brief: Just now there was a major clove harvest failure in Zanzibar and Madagascar. The price for one pikul of clove increased, from $f 75$ to $f 160$. Not yet known when all of these would recover as it used to be. Usually, high quality clove could only be harvested after 4.5 to 6.5 years. Quite a long time for hoping something that was uncertain. (p. 167)

The shortage of high-quality clove due to harvest failure made the price soar. As a result, production cost was getting higher. Some factories reduced the quantity or quality of clove that was normally used by using local clove. A few months later, several small and medium scale kretek cigarette factories started to close their business. They did not have enough money to cover the increasing production cost. The news spread quickly, and most cigarette factory workers became anxious and panicked.

"Consumers are disappointed. The flavor of some brands has changed abruptly. It is their fault. Apparently, because of the increasing price of clove, some factories cut their workers' wages recklessly. So, the workers retaliated. The clove they used were substituted with the clove whose quality was bad. There were also some factories that deliberately mixed the imported clove with the local ones. The flavor becomes terrible," said Mister Karmain. (p. 167)

Although the price of clove and the production cost were high, some factories were unable to increase the price of their products. The kretek cigarette consumers switched to filter and non-clove cigarettes. This caused $k r e t e k$ cigarette factory a double loss.

"If it is about the clove, let it be. The impact is obvious. Raising the price, reducing the quantity of the clove used, or substituting the imported clove with the local one would make the consumers abandon the kretek cigarettes. They might shift to filter cigarettes," continued Mister Soedjoko. (p. 173)

When the economic crisis was over, kretek cigarette factories in Kudus started their production again. Soon afterwards, the economy of Kudus began to recover. The workers of Bal Tiga factory worked passionately. The sales and production increased significantly within one year.

Perhaps because of the excitement after being idle for a long time, everyone worked passionately. As a result, within one year our sales and production were significantly improved when they were compared to those of previous year. (p. 201)

Kudus was brought back to life with a new determination that come from the public. There were no more sluggishness and gloominess all over the city. The spirit of working led Kudus to becoming a town which was advanced town in economy.

An improved economic climate was also clearly seen in every corner of the town. In fact, as reported by De Locomotief daily, the development in Kudus was really in contrast with the sluggishness that occurred in other places. After the malaise had passed, Kudus is like a reborn town, emerging from the ground. (p. 201)

\section{CONCLUSION}

The life of kretek cigarette workers reflected the existence of human values based on equality and freedom. Discrimination against kretek cigarette workers, who were bumiputra and low class, were resisted by Filip, depicted as a representation of the colonizer who view the natives as their fellow human beings. Filip's attitude of appreciating and respecting the natives was against the superior, racist, and discriminatory attitude of his own racial group. Filip's humanist attitude gave kretek cigarette workers a sense of security and comfort.

The recognition of the intelligence of Goenawan Wirosoeseno, who came from the priyayi circles, as an employee of the kretek cigarette factory, represented Wirosoeseno's intelligence, equality, and freedom to develop a kretek cigarette factory. His priyayi position contributed to strengthening kretek cigarette workers' sense of acceptance and camaraderie as fellow Javanese natives. The spirit of egalitarianism and freedom led the kretek cigarette factory to being creative and innovative in adopting various productive marketing strategies. The successful approaches managed the factory to earn profits. The approaches helped it navigate the hardship of kretek cigarette business during the economic crisis. The struggle to sustain the kretek cigarette factory elevated their dignity and made them persistent, tough, and strong kretek cigarette workers. 


\section{REFERENCES}

Banu, I. (2017). Sang raja [The King]. Jakarta: Kepustakaan Populer Gramedia.

Castles, L. (1982). Tingkah laku agama, politik, dan ekonomi di Jawa: Industri rokok Kudus [Religious, political, and economic behavior in Java: Kudus cigarette industries]. Jakarta: Penerbit Sinar Harapan.

Chusna, A. (2016, March 23). Rokok klobot tak lekang oleh zaman [Klobot cigarettes are timeless]. Antara. Retrieved from https://jatim.antaranews. com/berita/174733/rokok-klobot-tak-lekangoleh-zaman

Damono, S.D. (1978). Sosiologi sastra: Sebuah pengantar ringkas [Sociology of Literature: A brief introduction] Jakarta: Pusat Pembinaan dan Pengembangan Bahasa Departemen Pendidikan dan Kebudayaan.

D’Astous, A., \& Bitz, P. (1995). Consumer Evaluation of Sponsorship Programmes. European Journal Marketing, 29(12), 6-22.

Endraswara, S. (2011). Metodologi penelitian sastra: Epistemologi, model, teori, dan aplikasi [Literary research methodology: Epistemology, model, theory, and application]. Yogyakarta: CAPS.

Faruk. (1994). Pengantar sosiologi sastra [Introduction to the sociology of literature]. Yogyakarta: Pustaka Pelajar.

Fathoni, R. S. (2019, June 1). Krisis Malaise dan Dampaknya Bagi Hindia Belanda [Malaise crisis and its impacts on the Dutch East Indies]. Wawasan Sejarah. Retrieved from http://wawasansejarah.com/krisis-malaise-hindia-belanda/

Furnivall, J. S. (1938). Netherlands India: A study of plural economy. Cambridge: Cambridge University Press.

Kartodirjo, S. (1992). Pendekatan ilmu sosial dalam metodologi sejarah [Sociological approach in the methodology of history]. Jakarta: PT. Gramedia.

Kuntowijoyo. (1987). Budaya dan masyarakat [Culture and society]. Yogyakarta: Tiara Wacana.

Legge, J. D. (1961). Central authority and regional autonomy in Indonesia: A study in local administration 1950-1960. Ithaca, N.Y.: Cornell University Press.

Lubis, N. L. (2009). Depresi: Tinjauan psikologis [Depression: A psychological review] Jakarta: Kencana Prenada Media Group.

Lubis, U. (2017, May 18). Melacak jejak sejarah di museum rokok kretek Kudus [Tracing the imprint of history in Kudus kretek cigarette museum]. Rappler. Retrieved from https://www. rappler.com/indonesia/gaya-hidup/170201melacak-jejak-sejarah-museum-rokok-kretekkudus

Margana, S. (2014). Kretek Indonesia, dari nasionalisme hingga warisan budaya [Indonesian kretek, from nationalism till cultural heritage]. Yogyakarta: Jurusan Sejarah Fakultas Ilmu Budaya Universitas Gajah Mada dan PUSKINDO.

Matanasi, P. (2016, October 24). Sekolah-sekolah di zaman Belanda [Schools during the Dutch Era]. Tirto. Retrieve from https://tirto.id/sekolahsekolah-di-zaman-belanda-bXbV

Nitisemito, A. S. (1980). Raja kretek Nitisemito [The kretek king Nitisemito] Kudus: n.p.

Nurgiyantoro, B. (2010). Teori pengkajian fiksi [Fiction analysis theory] Yogyakarta: Gadjah Mada University Press.

Padmo, S. (1991). Depresi 1929 dan dampaknya terhadap Hindia Belanda [1929 depression and its impacts on the Dutch East Indies]. Jurnal Humaniora, 2, 1-10.

Pradopo, R. D. (2002). Kritik sastra modern [Modern literary criticism]. Yogyakarta: Gama Media.

Ratna, N. K. (2007). Penelitian kualitatif [Qualitatif research]. Jakarta: Kencana Perdana Media Grup.

Sahrodji, A. (2017, October 4). Sejarah kretek di Indonesia yang sempat disebut 'rokok obat' [The history of kretek, which was once called 'medicinal cigarettes' in Indonesia]. Okezone. Retrieved from https://nasional.okezone.com/ $\mathrm{read} / 2017 / 10 / 03 / 337 / 1788041 /$ sejarah-kretek-diindonesia-yang-sempat-disebut-rokok-obat.

Semi, A. (1988). Kritik sastra [Literary Criticism]. Bandung: Penerbit Angkasa.

Simanjuntak, P. N. H. (1999). Pokok-pokok hukum perdata di Indonesia [The main principles of civil law in Indonesia] Jakarta: Djambatan.

Swingewood, A., \& Laurenson, D. (1972). Sociology of literature. London: Paladin.

Teew, A. (1988). Sastra dan ilmu sastra: Pengantar teori sastra [Literature and literary studies: An Introduction to literary theory]. Jakarta: Pustaka Jaya.

Wiyatmi. (2006). Pengantar kajian sastra [Introduction to literary studies] Yogyakarta: Kanwa Publisher.

Wiyatmi. (2008). Sosiologi sastra: Teori dan kajian terhadap sastra Indonesia [Sociology of literature: Theory and studies on Indonesian literature] Yogyakarta: Kanwa Publisher. 